This Journal is available in TelkomUniversity online Journals

\title{
Using Cash Flow Ratios To Establish A Manufacturing Bankruptcy Prediction Model
}

\author{
M. Sienly Veronica ${ }^{1}$, Ida Ida ${ }^{2}$, Vincent Tanu Winata ${ }^{3}$ \\ 1,2,3 Program Studi Manajemen, Maranatha Christian University, Bandung, West Java, Indonesia
}

\begin{abstract}
This research has the purpose of forming a bankruptcy prediction model that will occur in manufacturing companies that listed in Indonesia Stock Exchange using the ratio of cash flow because the manufacturing industry plays an important role in a country's economic development. Cash flow ratio and condition of financial difficulties are used as research variables. Non probabilistic sample with the type of purposive sampling is referred to as the method used in sampling at this research, because rather than the number of manufacturing companies used was 92 manufacturing companies. The method of data analysis in this research uses logistic regression and the results show that cash flow ratios can predict financial distress with operating cash flow margin is most useful in predicting financial difficulty. These findings can make manufacturing companies focus on cash flow ratios to avoid financial distress.
\end{abstract}

Keywords-Cash Flow Ratios, Logistic Regression, Manufacturing Industries, Financial Distress

\begin{abstract}
Abstrak
Penelitian ini mempunyai tujuan membentuk model prediksi kebangkrutan yang akan terjadi pada perusahaan manufaktur yang terdaftar di Bursa Efek Indonesia dengan menggunakan rasio cash flow karena industri manufaktur memberikan peranan penting dalam perkembangan ekonomi suatu negara. Rasio cash flow dan kondisi kesulitan keuangan digunakan sebagai variabel penelitian. Non probabilistik sampel dengan jenis purposive sampling disebut sebagai cara yang digunakan dalam penarikan sampel penelitian ini, sebab daripada itu jumlah perusahaan manufaktur yang digunakan sebanyak 92 perusahaan manufaktur. Adapun cara analisis data pada riset ini menggunakan logistik regresi dan diperoleh rasio cash flow dapat memprediksi financial distress dengan variabel operating cash flow margin yang paling berguna dalam memprediksi kondisi kesulitan keuangan. Temuan tersebut dapat menjadikan perusahaan manufaktur berfokus pada rasio cash flow untuk menghindarkan dari financial distress.
\end{abstract}

Kata kunci-Rasio Cash Flow, Regresi Logistik, Perusahaan Manufaktur, Financial Distress

\section{INTRODUCTION}

According to Airlangga Hartanto (Minister of Industry), manufacturing plays an important role in the economy. The manufacturing industry has an effect on increasing value added, increasing tax revenues and excise duties, absorbing human resources and foreign exchange revenues. Manufacturing growth is expected to reach 5\% in 2019 (Komalasari, 2019). Considering the important role of manufacturing in the Indonesian economy, it is necessary to know the state of the company if it is indicative of financial problems through the development of commercial bank forecasting models, as financial hardship can affect the liquidity of the capital market and economic development, so that approaches to creating and developing forecast models to reduce the loss and impact of bankruptcy become important (Nikbakht and Sharifi , 2010). One way to make a forecast model for bankruptcy is to analyze financial difficulties. The accuracy of the analysis of the financial difficulties of the company will help the company take preventive measures to prevent the company from avoiding losses (Sujimantoro and Muthmainnah, 2017).

\section{Article info}

Received (11/11/2019)

Revised (03/04/2020)

Accepted (30/06/2020)

Corresponding_author: hui_ie77@yahoo.com

DOI: $10.25124 /$ jmi.v20i2.3198

Copyright@2020. Published by School of Economics and Business - TelkomUniversity 
The way it can be done is to analysis the financial statements in such a way that it can know the financial results that have been achieved, as well as the weaknesses and strengths of the company. Companies can maintain their strengths and improve their weaknesses (Rachmawati, 2017). When forming a model to predict bankruptcy, financial ratios can often be used, namely accrual and cash-based financial ratios. The model formed can be used by companies, creditors and investors as the basis for making the right decision (Wijayanti and Marsono, 2014). This study aims to create a bankruptcy forecasting model using the cash flow ratio.

\section{LITERATURE REVIEW}

\section{A. Definition of Bankruptcy}

According to Hanafi (2004), two approaches can be used to define bankruptcy, including:

1. The flow approach, bankruptcy is illustrated by the condition that the company can't produce with enough cash flow.

2. The stock approach, the company is called bankruptcy if the amount of liabilities is greater than the number of assets.

\section{B. Indicators of Bankruptcy}

According to Almilia and Kristijadi (2003) and Foster (1986), there are several bankruptcy indicators, including:

1. Analyze current and future cash flows.

2. Analyze the company's strategy with consideration of potential competitors, the structure of relative costs, and the development of design in the industry, the company's ability to continue to increase spending, quality management, and others.

3. Analyze the company's monetary information and compare it with other companies. The analysis can focus on a single financial factor or a combination of financial variables.

4. External factors such as stock profitability and measurement of debt values.

\section{The Company's Bankruptcy Prediction Model}

Aziz and Dar (2006) state that the forecasting models for corporate insolvencies are divided into three categories:

1. Statistical models.

The statistical model is a model that follows standard modeling methods. This model focuses on the symptoms of a business failure in which the statistical model is a model that uses univariate and multivariate analysis to create predictive models for corporate insolvency.

2. AIES Model (Artificially Intelligent Expert System Models).

This model also focuses on the symptoms of business failure, where the variables used in the model are typically more than one variable or multivariate. The development of this model uses computer technology that provides information about the state of the company that fails or does not fail.

3. Theoretical models.

This model focuses on the qualitative causes of the failure. This model is formed from information that is based on opinions of theories about corporate failure. The theoretical model uses statistical techniques to quantitatively support the opinions of the theory on corporate failure.

\section{Type of Error In Bankcruptcy Prediction Model}

Accroding to Prihadi (2010), forming a business bankruptcy prediction model does not rule out the possibility. Possible errors arising from the prediction tool can be in two groups:

\section{Type I Error}

Type I error is an error that arises because the prediction tool indicates that the company is not bankrupt, but in reality the company is bankrupt. This causes high costs because it is predicted that it will not go bankrupt, so that investors will invest and in fact the company will go bankrupt and investors will lose some asset value. 


\section{Type II Error}

Type II error is lower cost. This happens because when investors predict a bankrupt company and then there is no investment, it turns out that the company is not actually bankrupt. In this case, the investor simply misses the opportunity to make a profit.

\section{E. Company's Cash Flow Statement}

Harahap (2007) state that the statement of cash flows contributes to an accurate input in relation to the revenue and costs incurred by a company at a given time based on the grouping of transactions in operating, financing and investment activities. Statements of cash flows are important for the analysis of financial statements and analysis such as company valuations, because instead they arise with cash flow-based ratios where the cash flow ratio is quite important for measuring bankruptcy and financial difficulties (Prihadi, 2010).

There are several cash flow ratios designed to analyze the financial performance of the company, such as Giacomino and Mielke (1993) that have developed nine cash flow ratios used to calculate the performance of a company called performance ratios that are divided into two parts, including efficiency and sufficiency ratio (Tulasi and Waluyo, 2009).

According to Prihadi (2010), the cash flow ratios are divided into two groups:

\section{Efficiency Ratio}

Efficiency ratio, the ratio describes how well the company produces cash flow. There are ratios that are used to see the condition of the company, namely:

1. Cash Flow Adequacy

This ratio calculates a mix of potential operating cash flows to cover the main needs of fixed asset expenditure, dividend payments and debt repayment (long-term). The result is that one can be interpreted as operating cash flow capable of meeting all of its needs.

2. Long-term Debt Payment This ratio shows how much operating cash flow is absorbed to pay long-term debt. The ratio is trying to find the relationship of long-term financing with sources and is used to pay.

3. Dividend Payout

The high ratio shows us how much the impact of dividend financing is on operating cash flow.

4. Reinvestment

It shows whether the operating cash flow is used for expenditure on fixed assets. Purchases of fixed assets that are calculated gross means only the total purchase. The purpose of this ratio is to measure investments in the form of fixed assets designated as a means of generating operating cash flow.

5. Debt Coverage

Debt coverage shows how much operating cash flow can be used to pay off all of the company's debts. Although the company's debt does not mature at the same time, the ratio may indicate how much the existence of debt in the company is capable of being covered by the operating cash flow.

6. Depreciation-Amortization Impact

This ratio is used if in the preparation of cash flow states the method used is the indirect method, where in the indirect method of operating cash flow it is calculated as a conversion of net income by addition to depreciation. The amount of the depreciation adjustment value shows the amount of depreciation expense in the company.

\section{Sufficiency Ratio}

Sufficiency ratio explains the adequacy of the cash flow to meet the needs of the company. In the sufficiency ratio there are several ratios including:

1. Cash Flow To Sales

2. This ratio calculates how much sales will be converted into operational cash flow. The higher the ratio means that more cash is generated from sales.

3. Operating Index

4. The operating index is the ratio between operating cash flow and revenue from continuous operations.

5. Cash Flow Return On Assets

6. This ratio is used to measure profits in cash flow units. This ratio should be higher than the usual ROA ratio, as the company generates a higher operating cash flow than the profit. 


\section{F. Development of Hypotheses}

Earnings or profits that the company does not necessarily describe the condition of the company may pay the obligations that are due, but the cash flow ratio derived from the company's cash flow statement can provide a more complete picture of the company's potential to form an adequate operating cash flow for payment obligations. This makes the operating cash flow ratio interesting to study whether it can be used as a model to predict bankruptcy of a company because of the inability of the company to finance obligations that are due will result in a financial failure.

The cash flow ratios to be examined in this study are Cash current debt coverage, Cash interest coverage, operating cash flow margins, Total Assets Return on Operating cash flow, and Earnings quality. The research conducted by Suwaidan (2003) shows that the Total Assets Return on Operating cash flow can be used to distinguish between insolvent and non-bankrupt companies. According to the findings by Alostaz (2015), the ratio of Cash current debt coverage, Cash interest coverage, operating cash flow margins and earnings quality can be used to predict bankruptcy in the industrial, insurance, investment and services sectors. Similarly, from Jones (2016) the ratio of total assets return on operating cash flow and earnings quality ratio is a positive estimate of the company's bankruptcy, which means that the higher the value of the ratio makes the possibility that the company will not go bankrupt or reduce the likelihood of the company going bankrupt. Madineh et al (2017) shows the variable cash current debt coverage and earnings quality illustrate the difference between bankruptcy companies and companies that are not bankrupt. Based on the results of the research described above, the research hypotheses to be tested is:

Ha: Cash Flow Ratios (Cash current debt coverage, Cash interest coverage, operating cash flow margins, Total Assets Return on Operating cash flow, Earnings quality) can predict financial distress.

\section{RESEARCH METHOD}

\section{A. Type of Research}

This type of research is a causal study to examine cash flow variables that can predict corporate financial distress.

\section{B. Data Collection Techniques}

The data used comes from the financial statement report that have been published on the company's website or the IDX website and then processed by researchers.

\section{Population and Sample}

The population of this research is 132 manufacturing companies listed on the Stock Exchange. Using a purposive sampling method, 92 manufacturing companies were obtained as a research sample. The sample criteria are manufacturing companies listed on the Indonesian Stock Exchange before 2013 and had a complete financial statement from 2013-2017. The indicator for companies experiencing financial distress are:

1. Operating profit negative for several years.

2. The company does not pay a dividend $>1$ year.

In the formation of bankruptcy prediction models, the sample should be grouped into analysis and validation samples (Munthe, 2009). Hair et al (2006) state that there is no defined reference in the sample grouping in analytical sample groups and validation sample groups. Thus in this study, the researchers used a ratio of 60\%:40\%, which means that 60\% of the total sample as an analytical sample that forms a corporate bankruptcy prediction model, and $40 \%$ are used as a validation sample used to test the predictive capability of a corporate bankruptcy prediction model that was formed.

\section{Definition of The Operationalization Variable}

This study uses the cash flow ratios as an independent variable and the dependent variable is the financial distress with the operational definition of variables. 
Table 1 Definition of The Operationalization Variable

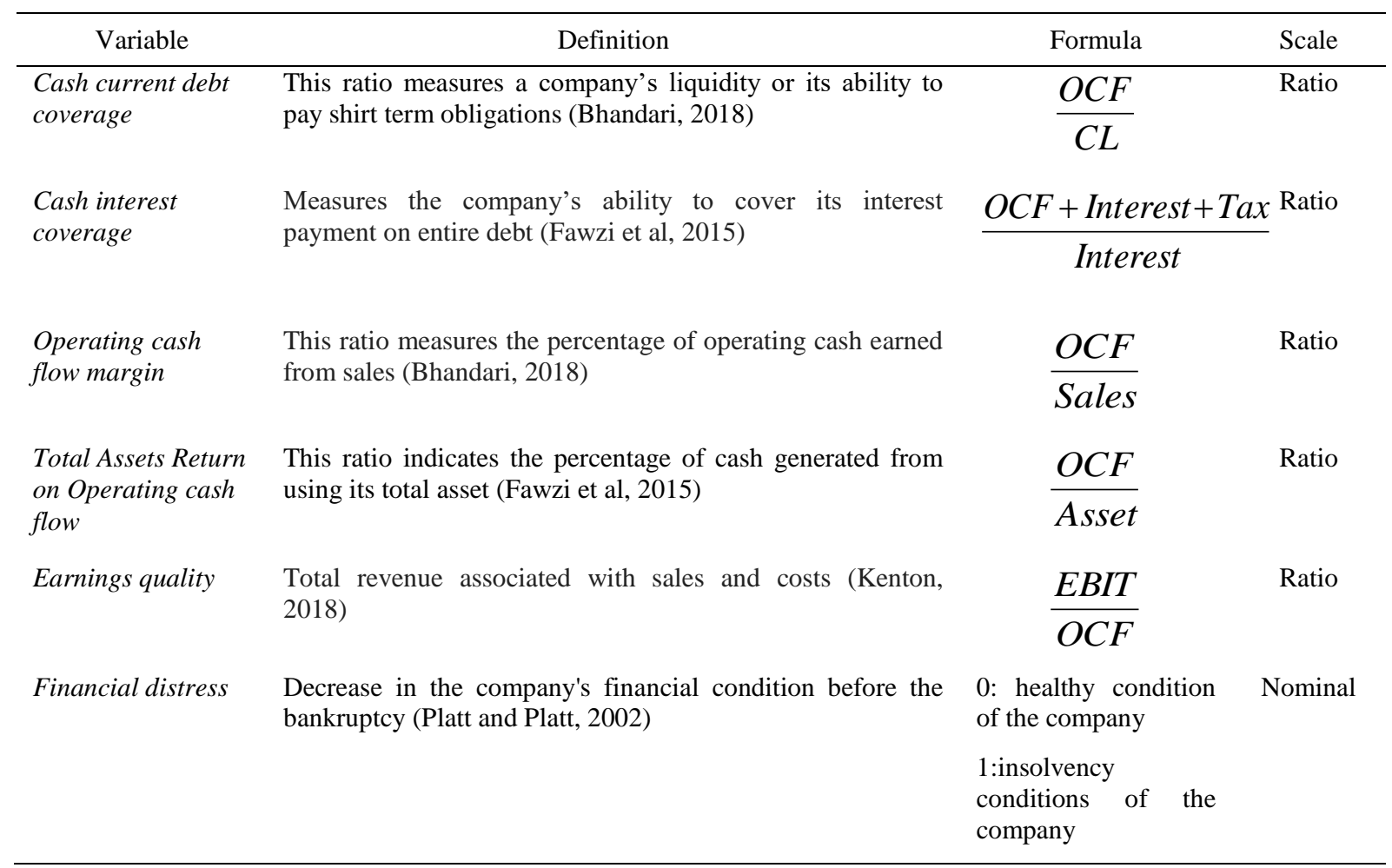

\section{E. Research Hypothesis Test}

The method for analyzing the data in this research is the logistic regression method because the dependent variable is the nominal scale, namely the condition of a healthy or insolvency company. According to Winarno (2007), the logistic regression model is:

$$
L_{i}=\ln \left(\frac{P_{i}}{1-P_{i}}\right)=\beta_{0}+\beta_{1} X_{1}+\beta_{2} X_{2}+\beta_{3} X_{3}+\ldots+\beta_{k} X_{k}+e_{i}
$$

Information:

P: $\quad$ The probability of a company not going bankrupt

$\mathrm{L}_{\mathrm{i}}: \quad$ Logit

$\beta_{0}: \quad$ A Constant

$\beta_{1^{-\mathrm{k}}}: \quad$ Regression Coefficient

$\mathrm{X}_{1-\mathrm{k}}: \quad$ Independent Variable

e $\quad$ Error

This study uses the likelihood ratio test for simultaneous testing of model parameters and Wald tests for partial testing (Hosmer and Lemeshow, 2000). Simultaneous testing uses simultaneous test hypotheses:

$\mathrm{H}_{0}: \beta_{1}=\beta_{2}=\beta_{3}=\ldots=\beta_{\mathrm{k}}=0$

$\mathrm{H}_{\mathrm{a}}$ : There's at least one $\beta_{\mathrm{i}} \neq 0 ; \mathrm{i}=1,2,3, \ldots, \mathrm{k}$

Statistic test G:

Information:

$$
G=-2 \ln \left(\frac{L 0}{L p}\right)
$$

$\mathrm{L}_{0}$ : Function without explanatory variables

$\mathrm{L}_{\mathrm{p}}$ : Function with explanatory variables

Rejection criteria $\mathrm{H}_{0}$ adalah $\mathrm{G}>\chi^{2} \mathrm{k}, \alpha$.

For partial tests, the partial test hypothesis is:

$\mathrm{H}_{0}: \beta_{\mathrm{i}}=0$ 
$\mathrm{H}_{\mathrm{a}}: \beta_{\mathrm{i}} \neq 0$;

$\mathrm{i}=1,2,3, \ldots, \mathrm{k}$

Test statistics $\mathrm{W}$ with the formula:

$$
W \hat{\beta}=\frac{\widehat{\beta}_{t}}{\widehat{S e}\left(\widehat{\beta}_{t}\right)}
$$

Information: $\widehat{\beta}_{t}$ as an estimator $\beta_{\mathrm{i}}$ and $\widehat{S e}\left(\widehat{\beta}_{t}\right)$ as a standard error estimate $\beta_{\mathrm{i}}$.

Assuming $\mathrm{H}_{0}$ right, The $\mathrm{W}$-test statistics will follow the standard normal distribution, then the criteria reject $\mathrm{H}_{0}$ if $|\mathrm{W}|>\mathrm{Z}_{\alpha / 2}$ or $\mathrm{p}$-value $<\alpha$.

\section{RESUltS AND DISCUSSION}

Before testing the research hypothesis: pass the suitability of the model test with Hosmerand Lemeshow's Goodness of Fit, the Enter method in logistic regression. The statistical hypothesis used to assess the fit model is:

- Observation hypothesis: The hypothetical model describes the research data.

- Alternative hypothesis: The hypothetical model does not describe research data.

The data processing results for testing the suitability of the model can be found in Table 2:

Table 2 Hosmer and Lemeshow's Goodnes of Fit

\begin{tabular}{llrl}
\hline Step & $\chi^{2}$ & df & Sig. \\
\hline 1 & 10.948 & 8 & .205 \\
\hline
\end{tabular}

The results of Hosmer and Lemeshow's Goodness of Fit show the significance value of 0,205, the significance value $>\alpha$ value $(0,05)$, because of that the observation hypothesis $\left(\mathrm{H}_{0}\right)$ is accepted, which means that the research data used is in accordance with the formed logistic regression equation model. Knowing that the resulting model is in line with the research data, the next thing to do is to test the research hypothesis where the research hypothesis: Cash Flow Ratio (Cash current debt coverage, Cash interest coverage, operating cash flow margins, Total Assets Return on Operating cash flow, Earnings quality) can predict financial distress. Using a method in logistic regression, the results of data processing are shown in Table 3:

Table 3 Omnibus Tests of Model Coefficients

\begin{tabular}{lccc}
\hline & $\chi^{2}$ & df & Sig. \\
\hline Step & 38.406 & 5 & .000 \\
Block & 38.406 & 5 & .000 \\
Model & 38.406 & 5 & .000 \\
\hline
\end{tabular}

\begin{tabular}{lccccc}
\hline & B & S.E. & Wald & df & Sig. \\
\hline Cash Current Debt Coverage & -.043 & .076 & .313 & 1 & .576 \\
Cash Interest Coverage & .000 & .000 & .688 & 1 & .407 \\
Operating Cash Flow Margin & -2.293 & 1.094 & 4.397 & 1 & .036 \\
Total Assets Return On & -5.606 & 2.873 & 3.807 & 1 & .051 \\
Operating Cash Flow & -.100 & .060 & 2.816 & 1 & .093 \\
Earning Quality & -2.120 & .298 & 50.653 & 1 & .000 \\
Constant & & & & &
\end{tabular}


Based on the information contained in Table 3, the significance of the Omnibus test of $0,000<\alpha(0,05)$ it can be stated that the cash flow ratio can predict financial distress. The results of this study are consistent with the research of Bhandari (2018) who revealed that using binary logistic regression found that the financial distress prediction model was statistically significant.

Looking at the variable of the cash flow ratio variable that can be used more to predict financial distress, the variable of the operating cash flow margin can be used to predict financial distress, since the significant value of the ratio is 0,036 .

The results of the research represent the sample used, that the manufacturing companies prioritizing increased sales in order to increase profit, so that the amount of operating cash flow can increase and be used to finance daily operating activities and can prevent the company from financial distress, because if the company has a good profit, the company can finance interest on debt in the short and long term. Financial distress occurs when the company's operating cash flow is negative, which means that the company does not have enough funds to pay for the company's day-to-day operations. This is stated by Prihadi (2010: 55) that if the operating cash flow is negative, this situation describes the company in a condition that has financial problems.

Financial distress prediction models that are formed based on the results of the hypothesis tests are: $\mathrm{Ln}(\mathrm{P} /$ $1-\mathrm{P})=-2,293 \mathrm{X}_{3}$ with the magnitude of the influence of the variables of operating cash flow margin in the prediction of financial distress of $38,3 \%$, while the remaining $61,7 \%$ of the occurrence of financial distress is caused by other factors.

Based on the prediction model that was formed, the accuracy level of predictions produced to predict accurately that manufacturing companies will experience financial distress or not was $87,5 \%$, table 4 below shows this.

Table 4 The Accuracy Rate of the Financial Distress Prediction Model

\begin{tabular}{llccc}
\hline \multicolumn{5}{c}{ Prediction } \\
\hline \multirow{3}{*}{ Observation } & 0 & 0 & 1 & $\%$ \\
& 1 & 244 & 1 & 99.59 \\
& & 34 & 1 & 97.14 \\
\hline
\end{tabular}

\section{CONCLUSIONS AND SugGestions}

Operating cash flow margin variable is the best predictor of financial distress. The researcher suggests developing this research using a different sample, entering macroeconomic variables and extending the observation time to obtain a more accurate financial distress prediction model.

\section{ACKNOWLEGMENT}

Thank you for the financial support from Maranatha Christian University, so that this research can be completed.

\section{REFERENCES}

Almilia, L.S., \& Kristijadi, E. (2003). Analisis Rasio Keuangan Untuk Memprediksi Kondisi Financial Distress Perusahaan Manufaktur yang Terdaftar di Bursa Efek Indonesia. Jurnal Akuntansi dan Auditing Indonesia (JAAI), 7(2).

Alostaz, A.O. (2015). Predicting Corporate Failure Using Cash Flow Statement Based Measures “ An Empirical Study on The Listed Companies in The Palestina Exchange. Thesis, Master of Business Administration, Islamic University of Gaza, Gaza. 
Aziz, M.A., \& Dar, H.A. (2006). Predicting Corporate Bankruptcy: Where We Stand? Corporate Governance, 16(1), 18-33.

Bhandari, S. (2018). A Generic Model Of Predicting Probability Of Success-Distress Of An Organization: A Logistic Regression Analysis. The Journal of Applied Business Research, 34(1),169-182.

Fawzi, N.S., Kamaluddin, A., \& Sanusi, Z.M. (2015). Monitoring Distressed Companies through Cash Flow Analysis. Procedia Economics and Finance, 28, 136-144.

Foster, G. (1986). Financial Statement Analysis. Second Edition, Prentice-Hall, Englewood Cliffs, N.J.

Giacomino, D.E \& Mielke, D.E. (1993). Cash Flow: Another Approach To Rario Analysis. Journal of Accountancy, 175(3), 55-60.

Hanafi, M.M. (2004). Manajemen Keuangan. Cetakan Pertama, BPFE-Yogyakarta, Yogyakarta.

Hair, J.F., Black, W.C., Babin, B.J., Anderson, R.E., \& Tatham, R.L. (2006.) Multivariate Data Analysis. Sixth Edition, Pearson International Edition.

Harahap, S.S. (2007). Analisis Kritis Atas Laporan Keuangan. Edisi Pertama, Cetakan Enam, Rajawali Pers, Jakarta.

Hosmer,D.W., \& Lemeshow, S. (2000). Applied Logistic Regression. Second Edition, John Wiley \& Son.Inc, United States of America.

Jones, S. (2016). A Cash Flow Based Model of Corporate Bankruptcy in Australia. JAMAR, 14(1), 23-38.

Kenton, W. (2018) 'Quality of Earnings' Investopedia $12 \quad$ Juli 2018. https://www.investopedia.com/terms/q/qualityofearnings.asp (diakses pada tanggal 14 Januari 2018).

Komalasari, T.D. (2019) Menperin Optimistis Pertumbuhan Manufaktur 2019 Capai 5\%. https://www.pikiranrakyat.com/ekonomi/2018/09/30/menperin-optimistis-pertumbuhan-manufaktur-2019-capai-5-430853, accessed 12 January 2019.

Kurniawan, A. (2014). Metode Riset untuk Ekonomi \& Bisnis Teori, Konsep, dan Praktik Penelitian Bisnis (Dilengkapi Perhitungan Pengolahan Data dengan IBMSPSS 22.0). Cetakan Kesatu, Alfabeta, Bandung.

Madineh, S.M., Sohrabi, A.R., Mohammadi, A., \& Veismoradi, A. (2017). Prediction of Financial Distress by Using Criteria for Cash Flow Statement in Companies Listed on the Tehran Stock Exchange. Journal of Administrative Management, Education and Training (JAMET), 13(2), 180-190.

Munthe, K. (2009) Pengaruh Sejumlah Variabel Makro Ekonomi dan Kinerja Keuangan Perusahaan Publik Terhadap Probabilitas Kesulitan Keuangan dan Kebangkrutan Periode Tahun 2001-2006 (Studi Pada Perusahaan Publik yang Tercatat di Bursa Efek Indonesia). Disertasi Tidak Dipublikasikan, Program Doktor Ilmu Ekonomi, Universitas Katolik Parahyangan, Bandung.

Nikbakht, M., \& Sharifi, M. (2010). Tehran Stock Exchange Companies' Bankruptcy Prediction by Using A Neural Network. Industrial Management, 4, 163-180.

Platt, H.D., \& Platt, M.B. (2002). Predicting Corporate Financial Distress: Reflection on Choice Based Sample Bias. Journal of Economics and Finance, 26(2), 184-199.

Prihadi, T. (2010). Analisis Laporan Keuangan: Teori \& Aplikasi. Cetakan I, PPM, Jakarta.

Rachmawati, D.W. (2017). Evaluasi Kinerja Keuangan PT Pupuk Sriwijaya Dilihat Dari Rasio Likuiditas', Jurnal Manajemen Indonesia, 17(3), 205-218.

Sujimantoro \& Muthmainnah. (2017). Analisis Kondisi Kebangkrutan dengan Model Ohlson (1980) O-Score. Future Jurnal Manajemen dan Akuntansi, 4(2), 153-169.

Suwaidan, M. (2003). The Ratio Model Versus The Cash Flow Model And The Prediction of Bankruptcy: An Empirical Examination. Abhath Al-Yarmouk Journal, 19(2B), 89-104.

Tulasi, D. \&Waluyo, F.X. A.J. (2009). Perbandingan Keakuratan Rasio-Rasio Keuangan Tradisional dengan Rasio-Rasio Cash Flow dalam Memprediksi Kinerja Keuangan Perusahaan. Proceding Konferensi Nasional I, Universitas Kristen Duta Wacana, Yogyakarta, 56-93.

Utami, N.W. (2018). Mengenal dan Mencegah Terjadinya Financial Distress dalam Perusahaan. https://www.jurnal.id/id/blog/2018-mengetahui-dan-mencegah-terjadinya-financial-distress-dalamperusahaan/, accessed 14 Januari 2018.

Wijayanti, A., \& Marsono. (2014). Analisis Ketepatan Prediksi Kebangkrutan: Studi Banding Menggunakan Pendekatan Berbasis Akrual dan Aliran Kas (Studi Kasus Pada Perusahaan Manufaktur yang Terdaftar di Bursa Efek Indonesia Tahun 2009-2012). Diponegoro Journal of Accounting, 3(3), 1-9. http://ejournal-s1.undip.ac.id/index.php/accounting (diakses pada tanggal 12 Januari 2019).

Winarno,W.W. (2007). Analisis Ekonometrika dan Statistika dengan Eviews. Cetakan Pertama, Sekolah Tinggi Ilmu Manajemen YKPN, Yogyakarta.

www.idx.co.id 